\title{
Analysis of a Frame-Shear Wall Concrete Structure by Using Base Isolation and Evaluation of Structure- Soil Interaction
}

\author{
Halil Ibrahim Polat \\ Ministry of Environment and Urbanization \\ Istanbul, Turkey \\ halilibrahimpolat34@gmail.com
}

\begin{abstract}
A base isolation system is a type of earthquakeresistant structure design approach based on the principle of reducing a structure's earthquake response rather than increasing the structure's earthquake resistance capacity. Seismic base isolated structures have the ability to make large displacements relative to the level of insulation elements. This means that a large structure performs very small displacements between floors during an earthquake and exhibits a rigid body behavior. At this point, the earthquake forces acting on the structure decrease along with the floors. In this article a school building composed of frame-shear wall is resolved primarily with the traditional fixed base structure system, mode shapes are found and periods are obtained. For earthquake response analysis, earthquake loads are distributed to the floors using the equivalent seismic load method and structural elements experiencing capacity problems are found. Then, using the earthquake record, larger failure of cross sections and capacity problems are obtained compared to the first method. In the second stage, the same structure is dissolved again by placing the lead core rubber base isolators between the base and the vertical structural members. The periods of structures under earthquake load have increased significantly by utilizing base isolation, as a result of that spectral accelerations decreased. Thus, large decreases in the shear forces acting to the structure are determined and failures of cross sections are removed.
\end{abstract}

Keywords-base isolation; construction-soil interaction; time history analysis

\section{INTRODUCTION}

One of the areas of interest of building and geotechnical earthquake engineering is the examination of the extent of damage occurred due to loads caused by lateral effects such as earthquakes and winds, the developing of suggestions against destructive effects and sustaining the relationship between the ground and the structure. In this context, it can be considered that the ground-structure interaction is the basic argument of the structural analysis calculations, especially the selection of the load-bearing system. In traditional building design, the strengthening of the bearing system, in order to provide a significant seismic performance, leads to a rather rigid behavior. The choice of such a load-bearing system causes the structures to be subjected to more lateral forces and to shear loads. In this approach, the consumption of the seismic energy transferred through the structural ground is mainly due to the plastic hinges. Therefore, this means accepting the possible damage on the structure. Recently, the consumption of this energy is taken into consideration by means of some damping systems. These systems find use a method called base isolation. During the earthquake, the earth movement spreads in every direction in wave form and when it reaches a structure, starts shaking its foundation which shakes the load bearing system. Effects of inertia forces in the cross sections of the bearing system elements occur. Prevention of structure vibration by separating the foundation from the bearing system is the main idea of earthquake base insulation [1]. The strengthening of the load bearing system, in classical built-in structure design, increases the stiffness of the structure and results in augmenting structure's strength. On the other hand, base isolation is a kind of earthquake resistant structural design approach that focuses on the principle of reducing the response to earthquake rather than increasing the structure's resistance. In other words, the structures provide rigid body behavior, especially during large magnitude earthquakes, and structural constraints remain within elastic limits. Thus, a large part of the earthquake energy is consumed by the seismic isolator system and additional damping devices at the isolation level. So, a small portion of the earthquake energy is transmitted to the structure (Figure 1).
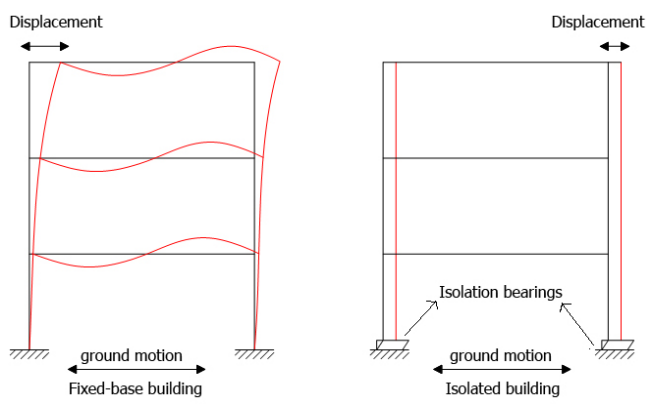

Fig. 1. Behaviour of fixed base structure and seismically base isolated structure during the earthquake 
A structure with a seismic isolation system can exhibit almost rigid superstructure behaviour in an earthquake motion as well as the flexibility needed to reduce floor accelerations with the isolation zone of large displacements. In this context, it has the rigidity required to reduce the relative floor displacements. During the first dynamic mode of the structures in which the base insulation systems are applied, the displacement is only at the isolation level. The top modes producing displacement are orthogonal to the first mode and hence the ground motion. Participation of these upper modes to the motion is very low (Figure 2) [2].

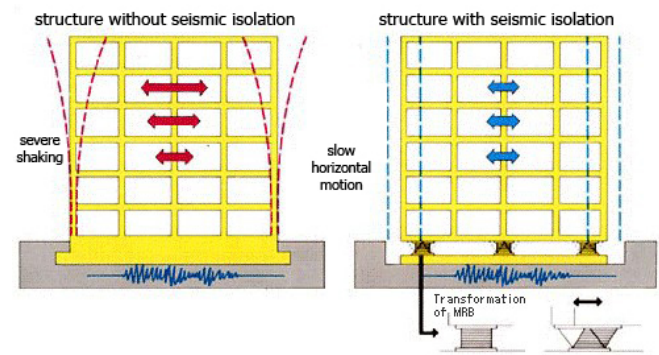

Fig. 2. Seismic isolator base displacement at base level

The effective resonance period of a structure is usually between 0.1 and 1.0 second. This period also includes the dominant period of many violent earthquakes [3]. Since the elastic first vibration periods of the seismic base insulated structures are considerably larger than the fixed base construction, the elastic first vibration periods are enlarged (Figure 3), it is provided to move away from the resonance zone, at which earthquake is very dangerous for structures. Thus, the magnitude of ground acceleration is prevented by the structure [4].

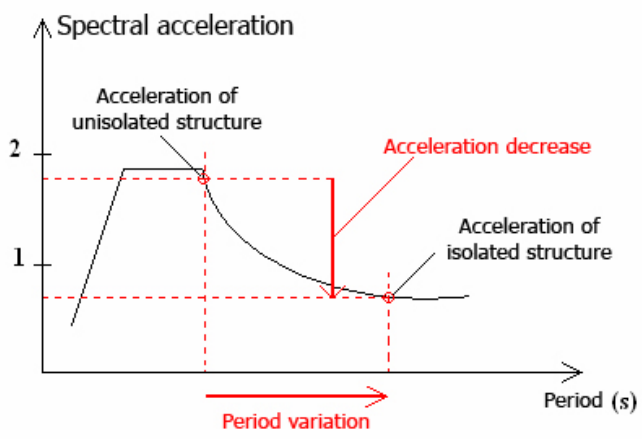

Fig. 3. A typical design spectrum

The basic characteristics that a seismic isolator system should have are [5]:

- Low enough horizontal stiffness

- High vertical stiffness (to allow the weight of the superstructure to be transported without deterioration)

- Enough damping (for a possible resonance condition)

- Back-centering effect (to return to pre-move position)

- Anti-collapse system

- Sufficient strength against tensile loads (in case of tensile strength)
The seismic insulation elements are placed on the foundation in structures that have no basement or in the lower, middle or upper sections of column and curtain elements in structures with basement $[6,7]$. In this study, a kind of leadcore rubber isolator in spherical form is used. The insulator is formed by joining the natural rubber layers with low damping with the help of steel reinforcement plates and by placing the cylindrical lead core in the middle. Lead material is a crystallized material that can temporarily change its form below the pour point. On the other hand, rubber has the effect of corrective force which restores the system to its original state and maintain its elastic characteristics. Lead-core is forced to change the plastic shape by the effect of the shear forces transmitted by the steel plates. In this context, the energy expenditure mechanism of lead-core rubber isolators is related to the elasto-plastic behaviour of rubber and lead [6]. Natural rubber isolations have many advantages:

- Simple production

- Easy modelling

- Bearings mechanical behavior of is not affected by speed, temperature and aging over time [8].

\section{EXISTING SYSTEM ANALYSIS}

With the help of the Etabs program, an existing 3-storey (consisting of ground floor +2 typical floors) school building with a reinforced concrete curtain-framed load bearing system, with $21,60 \times 14,35 \mathrm{~m}$ dimensions, storey height: $3.00 \mathrm{~m}$ is analyzed and its results are tried to be evaluated [9].

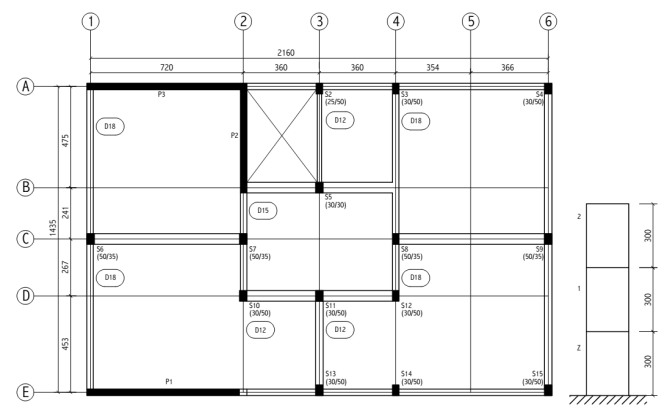

Fig. 4. Floor plan and section of the curtain-frame structure

The thickness of all curtains is $25 \mathrm{~cm}$. There are three types of column sections available (Table I). The largest beam dimension in the structure is $35 \times 70$ and the smallest is $25 \times 40$ (Table II). Also, there are three types of floor slabs of 12, 15 and $18 \mathrm{~cm}$.

TABLE I. COLUMN SECTIONS ACCORDING TO FLOORS

\begin{tabular}{|c|c|c|c|}
\hline \multirow{4}{*}{ Floor } & $\begin{array}{c}\text { SZ02- } \\
\text { SZ05 }\end{array}$ & $\begin{array}{c}\text { SZ03-SZ04-SZ10-SZ11- } \\
\text { SZ12-SZ14-SZ15-SZ16 }\end{array}$ & $\begin{array}{c}\text { SZ06-SZ07- } \\
\text { SZ08-SZ09 }\end{array}$ \\
\cline { 2 - 4 } & S102-S205 & $\begin{array}{c}\text { S103-S104-S110-S111- } \\
\text { S112-S114-S115-S116 }\end{array}$ & $\begin{array}{c}\text { S106-S107- } \\
\text { S108-S109 }\end{array}$ \\
\cline { 2 - 4 } & $\begin{array}{c}\text { S202- } \\
\text { S205 }\end{array}$ & $\begin{array}{c}\text { S203-S204-S210-S211- } \\
\text { S212-S214-S215-S216 }\end{array}$ & $\begin{array}{c}\text { S206-S207- } \\
\text { S208-S209 }\end{array}$ \\
\hline $\mathbf{G}$ & $25 \times 50$ & $30 \times 50$ & $50 \times 35$ \\
\hline $\mathbf{1}$ & $25 \times 50$ & $30 \times 50$ & $50 \times 35$ \\
\hline $\mathbf{2}$ & $25 \times 50$ & $30 \times 50$ & $50 \times 30$ \\
\hline
\end{tabular}


TABLE II. BEAM SECTIONS ACCORDING TO FLOORS

\begin{tabular}{|c|c|c|l|l|l|}
\hline & K101-K102- & K104-K108- & & & \\
& K103-K110- & K109-K118- & & & \\
& K111 & K119 & \multirow{2}{*}{ K105 } & K106- & \multirow{2}{*}{ K117 } \\
& K112-K114- & K121-K122- & K107 & \\
& K115-K126- & K123-K124- & & & \\
& K127 & K125 & & & \\
\cline { 2 - 6 } & K201-K202- & K204-K208- & & & \\
& K203-K210- & K209-K218- & & & \\
& K211 & K219 & \multirow{2}{*}{ K205 } & K206- & \multirow{2}{*}{ K217 } \\
& K212-K214- & K221-K222- & K207 & \\
& K215-K226- & K223-K224- & & & \\
& K227 & K225 & & & \\
\cline { 2 - 6 } & K301-K302- & K304-K308- & & & \\
& K303-K310- & K309-K318- & & & \\
& K311 & K319 & K305 & K306- & \multirow{2}{*}{ K317 } \\
& K312-K314- & K321-K322- & & K307 & \\
& K315-K326- & K323-K324- & & & \\
\hline $\mathbf{G}$ & K327 & K325 & & & \\
\hline $\mathbf{1}$ & $30 \times 70$ & $25 \times 50$ & $25 \times 40$ & $35 \times 70$ & $25 \times 70$ \\
\hline $\mathbf{2}$ & $30 \times 70$ & $25 \times 50$ & $25 \times 40$ & $35 \times 70$ & $25 \times 70$ \\
\hline
\end{tabular}

C14 concrete and CSI non-ribbed steel are used in the construction. Cross section and material selection of all structural elements have been made according to the existing axle system. Movable and constant load distributions are provided and the bearings are defined (Figure 5).

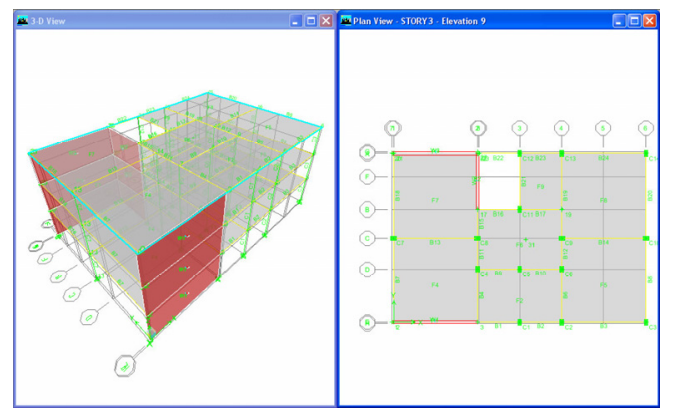

Fig. 5. Building plan and three-dimensional view

As a result of the analysis, the natural vibration periods of the building are determined. According to this; the 1st mode of the building is in the Y direction and 0.2165 s. (Figure 6). The second mode of construction is $0.1447 \mathrm{~s}$ in the $\mathrm{Z}$ direction. The third mode is $0.110 \mathrm{~s}$ in the $\mathrm{X}$ direction (Figures 7 and 8).

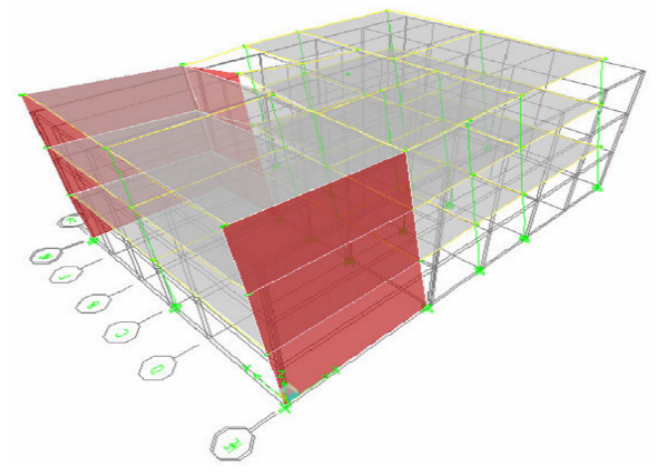

Fig. 6. 1st mode $(\mathrm{T} 1 \mathrm{Y}=0.2165 \mathrm{~s})$

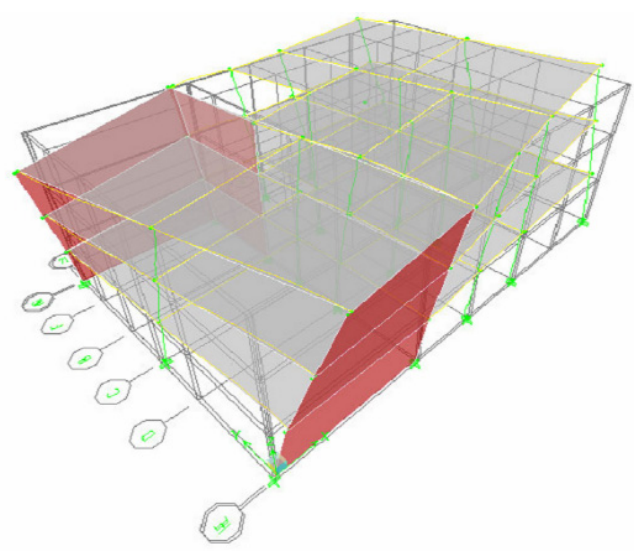

Fig. 7. 2nd Mode Shape $(\mathrm{T} 1 \mathrm{Z}=0.1447 \mathrm{~s})$

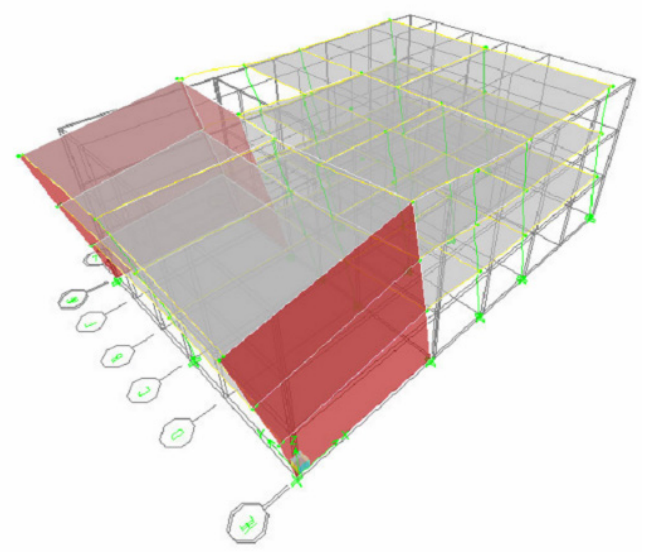

Fig. $8 . \quad 3$ rd Mode Shape $(\mathrm{T} 1 \mathrm{X}=0.1110 \mathrm{~s}$.

After the mode shapes are obtained, the shear wall-frame system is analyzed by linear equivalent seismic load method. In the second phase, nonlinear analysis is performed in time domain by using the data, including east-west and north-south directional components, recorded at 1999 Marmara earthquake in Duzce meteorology station. After these two analyses were completed, the base isolation is added to the fixed-base system, and the system is re-solved in the time domain and all three cases are compared (cross section insufficiencies, period, mode shapes, etc.).

\section{A. Earthquake Analysis by Equivalent Seismic Load Method (Current System)}

Equivalent Seismic Load Method (ESLM) and lateral seismic loads are defined at floor alignments with \pm 0.05 eccentricity. Building earthquake parameters:

- Effective ground acceleration coefficient: A0 $=0.40$ (1st degree earthquake region)

- Significance coefficient of the building: $\mathrm{I}=1.4$ (School building)

- Spectrum characteristic period: $\mathrm{TA}=0.15, \mathrm{~TB}=0.60(\mathrm{Z3}$ soil class)

- Load bearing system behavior coefficient: $\mathrm{R}=4$ (ductility level normal system) [10] 
A total of 21 load combinations are defined. According to the analysis made by reflecting the parameters of the ESLM, none of the columns belonging to the structure are found to be inadequate in cross section. As seen in Table III, the capacity has been exceeded at the bending of P3 shear-wall in the 1st floor (ground floor). In addition, as shown in Table IV, the P2 shear-wall in the 1st and 2nd storeys, and the P3 shear-wall in the 1st storey have capacity problem (Figure 9 ).

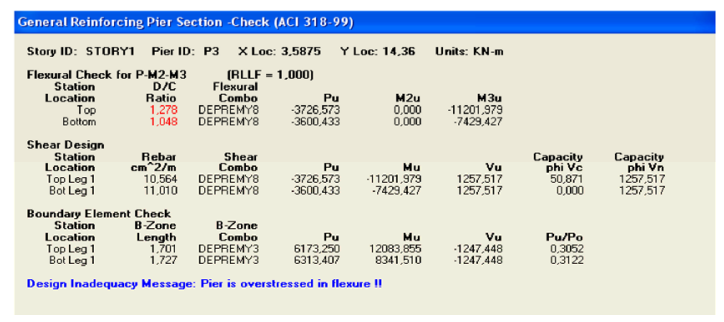

Fig. 9. Capacity problems in shear walls in ESLM

TABLE III. CAPACITY PROBLEMS IN SHEAR WALLS IN ESLM

\begin{tabular}{|c|c|c|}
\hline \multicolumn{3}{|c|}{ Shear-walls } \\
\hline 1st floor & 1st floor & 1st floor \\
\hline- & - & - \\
\hline P2 & P2 & - \\
\hline P3 & - & - \\
\hline
\end{tabular}

\section{B. Earthquake Analysis with Time History Method (Current System)}

The current system model has been solved with time history method without any changes in material characteristics and cross sections. Acceleration records of 1999 Marmara earthquake recorded at Duzce meteorology station are utilized (Figures 10 and 11). The time period is $0.005 \mathrm{~s}$, the maximum acceleration value is $3.73 \mathrm{~m} / \mathrm{s}^{2}$ for East-West and $3.14 \mathrm{~m} / \mathrm{s}^{2}$ for North-South. According to the analysis results, in all three floors, shear-walls are found to be inadequate (Table IV). In vertical load bearings, 15 of the 42 existing columns are found to be inadequate (Table V).

TABLE IV. CAPACITY PROBLEMS IN SHEAR-WALL ELEMENTS IN THE TIME DEFINITION AREA

\begin{tabular}{|c|c|c|}
\hline \multicolumn{3}{|c|}{ Shear-walls } \\
\hline 1st floor & 2nd floor & 3rd floor \\
\hline P1 & P1 & - \\
\hline P2 & P2 & - \\
\hline P3 & - & - \\
\hline
\end{tabular}

TABLE V. COLUMNS EXCEEDING THE CAPACITY RATIO LIMIT

\begin{tabular}{|c|c|c|}
\hline \multicolumn{3}{|c|}{ Columns } \\
\hline 1st floor & 2nd floor & 3rd floor \\
\hline SZ02 & S102 & S202 \\
\hline SZ05 & - & - \\
\hline SZ07 & S107 & S207 \\
\hline SZ10 & S110 & S210 \\
\hline SZ11 & - & - \\
\hline SZ12 & - & - \\
\hline SZ14 & S114 & - \\
\hline SZ15 & - & - \\
\hline
\end{tabular}

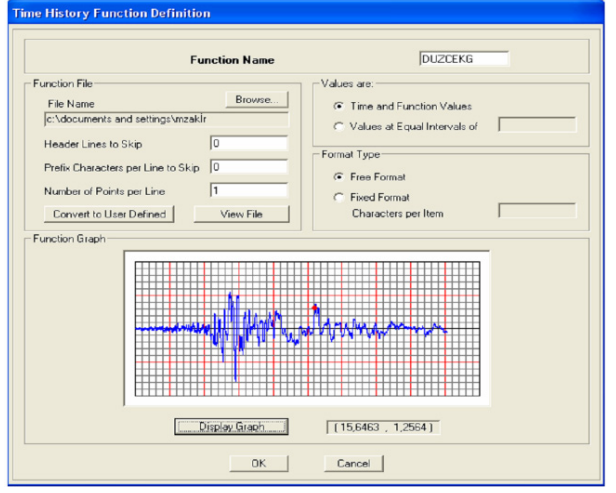

Fig. 10. Düzce north-south acceleration recording chart

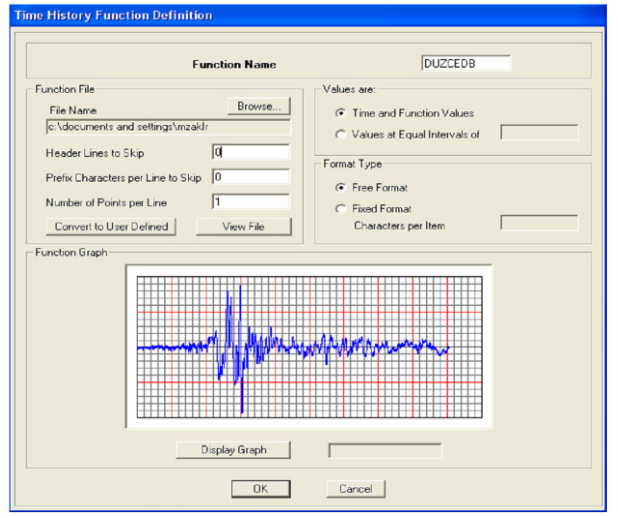

Fig. 11. Düzce east-west acceleration recording chart

\section{SYSTEM ANALYSIS OF BASE ISOLATIONS}

The analysis is renewed by placing the base isolation in the base-column junction of the present school building, which consists of shear wall-frame. DIS B type lead core rubber isolator manufactured by Dynamic Isolation Systems Company is used for the base isolation material. The characteristic of this isolator is shown in Table VI.

TABLE VI. CHARACTERISTIC FEATURES OF DIS B TYPE ISOLATOR

\begin{tabular}{|c|c|}
\hline Total weight of isolation element & $8.3404 \mathrm{kN}$ \\
\hline Effective rigidity for vertical direction & $\begin{array}{l}2.468 .654,085 \\
\mathrm{kN} / \mathrm{m} \text { (linear) }\end{array}$ \\
\hline Effective rigidity for horizontal direction & $\begin{array}{c}1.180,926 \\
\mathrm{kN} / \mathrm{m} \text { (linear) }\end{array}$ \\
\hline Effective rigidity for horizontal direction & $\begin{array}{l}6.808,12 \mathrm{kN} / \mathrm{m} \\
\text { (nonlinear) }\end{array}$ \\
\hline $\begin{array}{c}\text { Yield strength } \\
\end{array}$ & $127,03 \mathrm{kN}$ \\
\hline $\begin{array}{l}\text { The ratio of post-yield strength to pre-yield } \\
\text { strength }\end{array}$ & 0,1 \\
\hline
\end{tabular}

The linear and nonlinear damping of the isolator and the yield strength assignments are performed and the results are shown in Figure 12 [11]. The natural vibration frequency of the isolated structure has now been determined. According to this, the 1st mode of the building is $1.7407 \mathrm{~s}$ in the $\mathrm{Z}$ direction (torsional direction) (Figure 13). The second mode is $1.6550 \mathrm{~s}$ 
in the Y direction (Figure 14). The third mode is $1.6458 \mathrm{~s}$ in the $\mathrm{X}$ direction. (Figure 15).

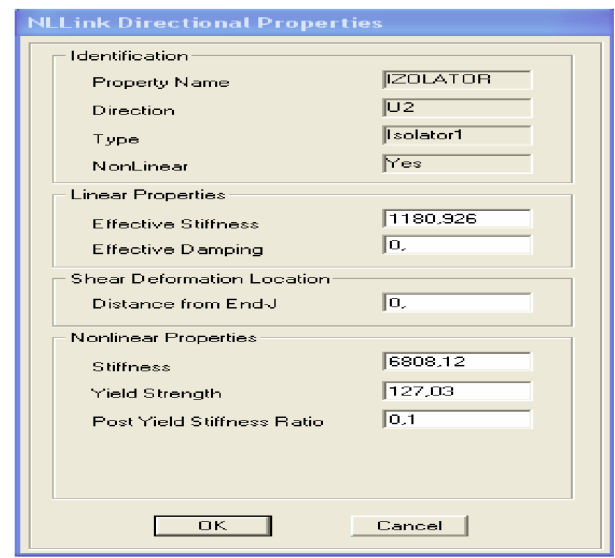

Fig. 12. Assign screen for characteristics of DIS B type isolator

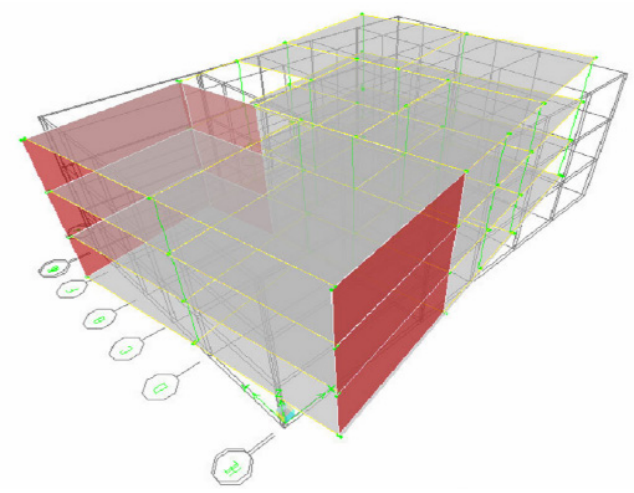

Fig. 13. 1st mode of isolator system with $(\mathrm{T} 1 \mathrm{Z}=1.7407 \mathrm{~s}$.

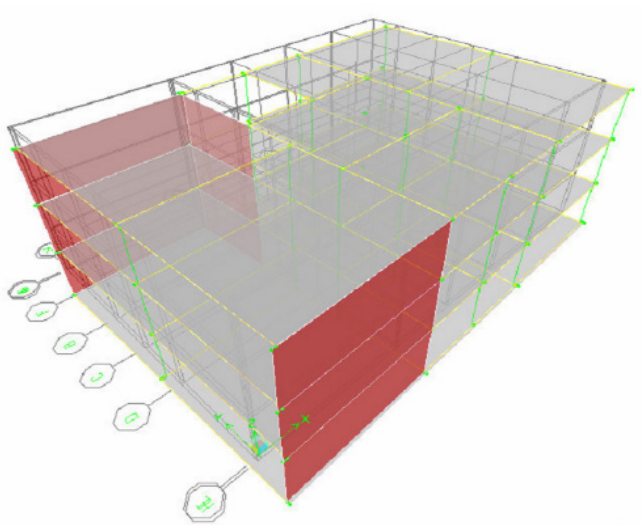

Fig. 14. 2nd mode of isolator system with (T1Y=1.6550s.)

\section{EARTHQUAKE ANALYSIS WITH BASE ISOLATOR IN TIME HISTORY METHOD}

The existing system with base isolation has also been solved in nonlinear time history method. As a result of the analysis made on the basis of the acceleration records in Figures 10 and 11, it is seen that all the sections are sufficient in contrast to the current situation and no capacity problem is encountered. The $1 \mathrm{st}$ period of the classical analysis is $0.2165 \mathrm{~s}$ in the $\mathrm{Y}$ direction. While the 1 st period of the base isolated system is in the direction of $\mathrm{Z}$ (torsion direction) and equal to $1.7407 \mathrm{~s}$.

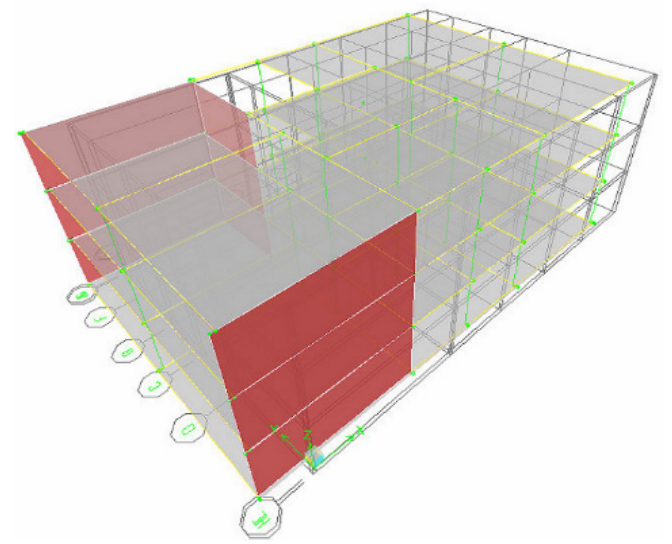

Fig. 15. 3rd mode of isolator system with $(\mathrm{T} 1 \mathrm{X}=1.6458 \mathrm{~s}$. $)$

\section{CONCLUSION AND EVALUATION}

According to the nonlinear time history method it is seen that the cross sectional insufficiency is more than ESLM. For this reason, the application of the base isolation is made on the basis of the time history method in the context of the "safety engineering principle". With the assignment of DIS B type lead-core rubber isolator, the analysis is revised and compiled as shown in Table VII. According to this, it has been seen that with the base isolation application, the natural periods increased from about 8 to 16 times for all three directions compared to the fixed-base building. As a result, the spectral acceleration decreased in the base isolation system and decrease in the shear forces is observed. In addition, during the reflected earthquake, there is a very small displacement between the floors, rigid body behaviour and the deformations remained especially at the isolator level.

TABLE VII. COMPARATIVE PERIOD TABLE

\begin{tabular}{|c|c|c|c|}
\hline \multicolumn{4}{|c|}{ Shear wall-Frame System } \\
\hline \multirow{2}{*}{ Fixed-base system } & T1X & T1Y & T1Z \\
\cline { 2 - 4 } & 0.111 & 0.2165 & 0.1447 \\
\hline Base isolation system & 1.6458 & 1.655 & 1.7407 \\
\hline
\end{tabular}

The results of the analysis of the generated system are summarized in Table VIII. A capacity problem occurred in some shear walls in fixed-base structure with the solution of ESLM. In the results of the earthquake calculations using the nonlinear time-history method, bending capacity in almost all column and shear wall sections is found to be inadequate. On the other hand, it is seen that there is no capacity problem in the insufficient sections of the structural system components. As a result, seismic isolator systems have proven that the structure can be dimensioned for smaller loads during the design of a 
new structure. It is thought that the application area of base isolation should be increased as an alternative solution method in order to construct more secure structures in regions where settlement density is clustered on the North Anatolian Fault Line.

TABLE VIII. COMPARATIVE CAPACITY TABLE

\begin{tabular}{|c|c|c|c|c|c|c|c|c|}
\hline \multicolumn{9}{|c|}{ Structural elements exceeding capacity } \\
\hline \multicolumn{3}{|c|}{$\begin{array}{l}\text { Fixed bearing solution with equivalent seismic load } \\
\text { method }\end{array}$} & \multicolumn{3}{|c|}{ Fixed bearing solution with time history method } & \multicolumn{3}{|c|}{ Base isolator solution with time history method } \\
\hline 1st floor & 2nd floor & 3rd floor & 1st floor & 2nd floor & 3rd floor & 1st floor & 2nd floor & 3rd floor \\
\hline- & - & - & SZ02 & S102 & S202 & - & - & - \\
\hline- & - & - & SZ05 & - & - & - & - & - \\
\hline- & - & - & SZ07 & S107 & S207 & - & - & - \\
\hline- & - & - & SZ10 & S110 & $\mathrm{S} 210$ & - & - & - \\
\hline- & - & - & SZ11 & - & - & - & - & - \\
\hline- & - & - & SZ12 & - & - & - & - & - \\
\hline- & - & - & SZ14 & $\mathrm{S} 114$ & - & - & - & - \\
\hline- & - & - & SZ15 & - & - & - & - & - \\
\hline- & - & - & P1 & P1 & - & - & - & - \\
\hline P2 & P2 & - & P2 & $\mathrm{P} 2$ & - & - & - & - \\
\hline P3 & - & - & P3 & - & - & - & - & - \\
\hline
\end{tabular}

\section{REFERENCES}

[1] Z. Celep, N. Kumbasar, Deprem Muhendisligine Giris ve Depreme Dayanikli Yapi Tasarimi, Beta Publisher, 2004

[2] http://www.mafiamax.com/2012/06/evim-depreme-dayanikli-mi.html, 2017

[3] S. Pinarbasi, U. Akyuz, "Sismik izolasyon ve Elastomerik Yastik Deneyleri”, IMO Teknik Dergi, Vol. 237, pp. 3581-3598, 2005

[4] R. Pekgokgoz, Deprem Yukleri Altindaki Yapi Davranisinin Yari-Aktif Akiskanli Sonumleyiciler ve Sismik Taban Yalitim Sistemleri Kullanilarak Bulanik Mantik Yontemi ile Kontrolu, PhD Thesis, Institute of Science, Istanbul Technical University, 2005

[5] J. M. Kelly, "Seismic Isolation as an Innovative Approach for the Protection of Engineered Structures", 11th European Conference on Earthquake Engineering, pp. 338, 1998

[6] www.arfen.com.tr, 2017

[7] www.erseteknoloji.com, 2017

[8] H. Turker, Taban Izolasyonu ile Klasik Guçlendirme Arasinda Bir Maliyet Karsilastirilmasi, MSc Thesis, Institute of Science, Istanbul Technical University, 2003

[9] H. I. Polat, Perde-Cerceve ve Cercevelerden Olusan Yapilarin Taban Izolatorleri Kullanilarak Analizi ve Degerlendirilmesi, MSc Thesis, Institute of Science, Istanbul Technical University, 2007

[10] Ministry of Environment and Urban Planning, Deprem Bolgelerinde Yapilacak Yapilar Hakkinda Yonetmelik, Bayindirlik ve Iskan Bakanligi, 2007

[11] G. Ozmen, E. Orakdogen,K. Darilmaz, Orneklerle ETABS, Birsen Yayinevi, 2005 